\title{
Improvement of Rice Seedling Establishment in Sulfate-Applied Submerged Soil by Application of Molybdate
}

\author{
Yoshitaka Hara \\ (NARO Kyushu Okinawa Agricultural Research Center, 496 Izumi, Chikugo, Fukuoka 833-0041, Japan)
}

\begin{abstract}
Sulfide ion generation in strictly reduced soil might be a factor impairing rice seedling establishment. The molybdate ion is known to suppress the microbial transformation of sulfide ions from sulfate ions. I investigated the effect of molybdate on rice establishment in sulfateapplied submerged soil. The establishment of rice seeds sown in sulfate-applied submerged soil was markedly improved by application of potassium molybdate at a rate of $1.5-15 \mathrm{mmol} \mathrm{kg} \mathrm{dried}^{-1}$ soil. The application of potassium molybdate delayed the decline of the sulfur concentration in the soil solution near the seeds and the appearance of circular black stains, or insoluble iron sulfide indicating the generation of sulfide ion, around seeds in the soil. Irrespective of the application of molybdate, the redox potential near the seeds was low enough to allow generation of sulfide ions, implying that molybdate suppresses the generation of sulfide ions with no effect on redox potential. These results suggest that the application of molybdate could improve rice seedling establishment in sulfur-rich submerged soil by suppressing the generation of sulfide ions, that is a possible factor suppressing the establishment of rice seeds sown in sulfur-rich submerged soil.
\end{abstract}

Key words: Direct seeding, Establishment, Molybdenum, Paddy soil, Rice plants, Sulfate, Sulfide.

In direct seeding cultivation of rice plants (Oryza sativa L.), poor establishment is a major obstacle to the widespread use of this practice (Yamauchi, 1997; Furuhata, 2009). The sulfide ion is notorious for impairing roots of mature rice in hot summers in certain paddy fields, an impairment referred to as "autumn decline" (Okajima and Takagi, 1959). In addition, ammonium sulfate impairs the germination and subsequent growth of rice seeds and this impairment has been suggested to be caused by sulfide ions (Kawaguchi, 1944), which appear to be generated from sulfate ions when soil is reduced (Osugi and Kawaguchi, 1938). However, it is unclear whether sulfide ions are generated in actual direct seeding and whether they impair the establishment of directly seeded rice because rice direct seeding was conducted under conditions unfavorable for soil reduction, that is, cool springtime conditions in paddy fields, in which soil sometimes does not dry out prior to submergence. Yamamoto et al. (2004) reported that ammonium sulfate was the most detrimental among the major ammonium fertilizers for non-coated seeds in cold regions, although they did not discuss the possibility of sulfide ion generation as a cause of the suppressed establishment associated with ammonium sulfate treatment.

I found that sulfate salts impair the establishment of rice seeds sown in submerged soil, even under cool direct- seeding conditions in which the soil is not dried before submergence (Hara, 2013). In addition, the redox potential of the soil near the seed quickly dropped to levels low enough to generate sulfide ions, and the sulfur concentration in the soil solution near the seed decreased as black circles appeared around the seeds. This was suggested to be caused by the transformation of soluble sulfate ions into reactive sulfide ions near the seeds sown in submerged soil, that changed into insoluble black iron sulfide by binding with ferrous ions (Hara, 2013). These results led to the hypothesis that the establishment of rice seeds sown in submerged soil is impaired by harmful sulfide ions even in actual direct seeding when the soil has enough sulfate.

Molybdate salts have been reported to suppress the generation of sulfide ions from sulfate ions by sulfatereducing bacteria (Hori et al., 1990; Biswas et al., 2009). Sulfate ions and molybdate ions are competing divalent anions of similar size and it is known that sulfur also may competitively suppress the molybdenum uptake in plants (Marschner, 1995a; MacLeod et al., 1997).

In this study, I examined the effect of molybdate application on the rice establishment in sulfate-applied submerged soil. 


\section{Materials and Methods}

\section{Effect of molybdate on rice establishment (Exp. 1)}

Moist soil (fine-textured gray lowland soil, light clay) was obtained from the topsoil (ca. $0-10 \mathrm{~cm}$ in depth) of a paddy field located in Chikugo, Fukuoka Prefecture, Japan. The water content of the soil was about $25 \%$ by weight. The $\mathrm{pH}\left(\mathrm{H}_{2} \mathrm{O}\right)$ of the soil was 6.2 . The soil was passed through a 10-mm sieve without previous drying and then refrigerated until use to minimize changes in soil conditions (Hara, 2013). Wet soil equivalent to $100 \mathrm{~g}$ of dried soil was placed in pots $(8 \mathrm{~cm}$ in diameter, $8 \mathrm{~cm}$ high $)$. A solution containing potassium molybdate at $0.00,0.38$, $0.75,1.5,3.0,7.5,15$ or $30 \mathrm{mmol} \mathrm{kg}^{-1}$ dried soil, ammonium sulfate at $4 \mathrm{mmol} \mathrm{kg}^{-1}$ dried soil, and potassium chloride at $1 \mathrm{mmol} \mathrm{kg}^{-1}$ dried soil was added to each pot until the total amount of water was 1.5 times the weight of dried soil. The mixture was shaken for $1 \mathrm{hr}$ to imitate puddling in the field and then kept in a refrigerator for $2 \mathrm{~d}$. Rice seeds (cv. Hinohikari) were sterilized by being soaked in $70 \%$ ethanol and a fivefold diluted solution of commercial sodium hypochlorite solution (available chlorine $>5 \%$ ) for each $10 \mathrm{~min}$. Seeds slightly germinated after soaked in water at $10^{\circ} \mathrm{C}$ for $5 \mathrm{~d}$ and then in water at $30^{\circ} \mathrm{C}$ for $2 \mathrm{~d}$. Eight germinated rice seeds were sown at a soil depth of 15 $\mathrm{mm}$ in each pot. About $10 \mathrm{~mL}$ of soil solution were sampled immediately after sowing for analysis from two pots for each condition using vacuum tubes and porous pipes $5 \mathrm{~cm}$ long and $6 \mathrm{~mm}$ in diameter (Hara, 2013). The pots were placed in growth chambers maintained at a temperature of either 20 or $30^{\circ} \mathrm{C}$ and a light intensity of about $0.1 \mathrm{mmol} \mathrm{m}^{-2} \mathrm{~s}^{-1}$ for $12 \mathrm{hr} \mathrm{d}^{-1}$. Water level was maintained at about $15 \mathrm{~mm}$. Rates of emergence and establishment were measured $21-35 \mathrm{~d}$ after sowing. Seedling emergence was determined by the appearance of the coleoptile on the soil surface, and establishment was determined by the appearance of the third leaf. Only when the final rate of establishment was more than $20 \%$, did we estimate the median time to full establishment from daily measurements of the establishment rate using the Richards function (Hara, 1999). Six pots were examined for each condition. An additional pot for each condition was prepared to observe soil reduction and the generation of black iron sulfide. Methylene blue was added at a rate of 1 $\mathrm{g} \mathrm{kg}^{-1}$ of dried soil and seeds were sown on the inside surface of the clear glass pots.

\section{Effect of sowing depth on establishment with molybdenum (Exp. 2)}

Soil was prepared as in Exp. 1 except for the application rate of potassium molybdate, which was $1.5,3.0$, or 7.5

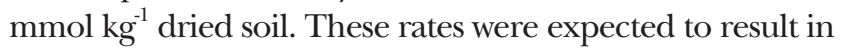
higher establishment based on the results of Exp. 1 in which seeds were sown at a 15-mm soil depth. Puddled soil was added to pots as needed to ensure adequate soil depth and eight germinated rice seeds were sown in each pot at soil depths of $20-40 \mathrm{~mm}$. Rates of emergence and establishment at $30^{\circ} \mathrm{C}$ were measured as in Exp. 1. Six pots were examined for each condition.

\section{Effect of molybdenum on soil redox potentials (Exp. 3)}

The application rate of potassium molybdate was 0.0 or $1.5 \mathrm{mmol} \mathrm{kg}^{-1}$ dried soil and pots were prepared as in Exp. 1. The latter concentration was expected to result in higher establishment and faster growth based on the results of Exp. 1. Following previously reported methods (Hara, 2013), a germinated rice seed (cv. Hinohikari) was attached to a platinum electrode with a polyethylene net. The platinum electrode and a comparison electrode were inserted into the submerged soil of the abovementioned pots at a soil depth of about $3 \mathrm{~cm}$. Pots were maintained at temperatures of either 20 or $30^{\circ} \mathrm{C}$ as in Exp. 1. Six pots were examined for each condition. The differences in electrical potential among these electrodes were automatically measured at hourly intervals for 2 wk using data loggers. The redox potential $(\mathrm{Eh}, \mathrm{V})$ versus the standard hydrogen electrode was calculated from the potential difference (PD, $\mathrm{V})$ and temperature $\left(\mathrm{T},{ }^{\circ} \mathrm{C}\right)$ using the following equation: $\mathrm{Eh}=\mathrm{PD}+0.206-0.0007 \cdot(\mathrm{T}-25)$.

\section{Effect of molybdenum on sulfur and molybdenum concentrations (Exp. 4)}

Pots were prepared as in Exp. 3. Following previously reported methods (Hara, 2013), pot soil solutions were sampled using $5 \mathrm{~cm}$ long, $6 \mathrm{~mm}$ diameter porous pipes and vacuum tubes. Two germinated rice seeds (cv. Hinohikari) were attached to a porous pipe with a polyethylene net and the pipe was then inserted into the bottom of the pot to sample the soil near the seed. The porous pipe was similarly inserted but without seed to sample the soil solution of unseeded soil. The pots were maintained as in Exp. 1. Two pots were examined for each condition. About $10 \mathrm{~mL}$ of soil solution was sampled using vacuum tubes at intervals of $2-3 \mathrm{~d}$, and $0.2 \mathrm{~mL}$ of $6 \mathrm{M}$ hydrochloric acid was added to prevent insolubilization. The concentrations of sulfur and molybdenum in the soil solution were analyzed using inductively coupled plasma atomic-emission spectroscopy (ICP-AES; Varian Vista AX).

\section{Results}

\section{Effect of molybdenum on rice establishment (Exp. 1)}

The rates of emergence and establishment of rice seeds maintained at temperatures of 20 and $30^{\circ} \mathrm{C}$ were similar (Fig. 1). Emergence rates were $30-50 \%$ when potassium molybdate was not applied, and this rate roughly increased with increasing amounts of potassium molybdate application. Establishment rates were less than $10 \%$ when the amount of potassium molybdate applied was no more 

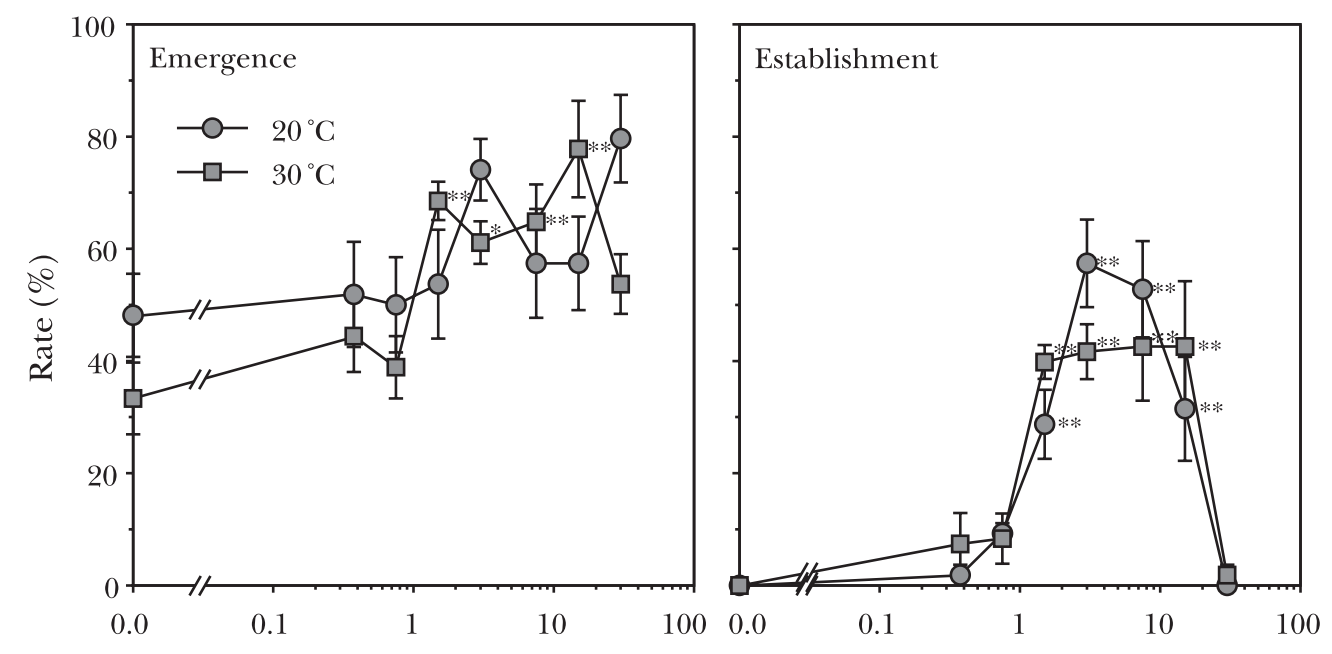

Applied amount of potassium molybdate $\left(\mathrm{mmol} \mathrm{kg}^{-1}\right.$ dried soil)

Fig. 1. Effect of molybdate on rates of seedling emergence and establishment.

Seeds were sown in soil to which different amounts of potassium molybdate were applied. Sown seeds were incubated at 20 or $30^{\circ} \mathrm{C}$. Error bars represent standard errors $(n=6)$. ** $p<0.01, * p<0.05$ vs. samples lacking potassium molybdate (Dunnett's multiple comparison).

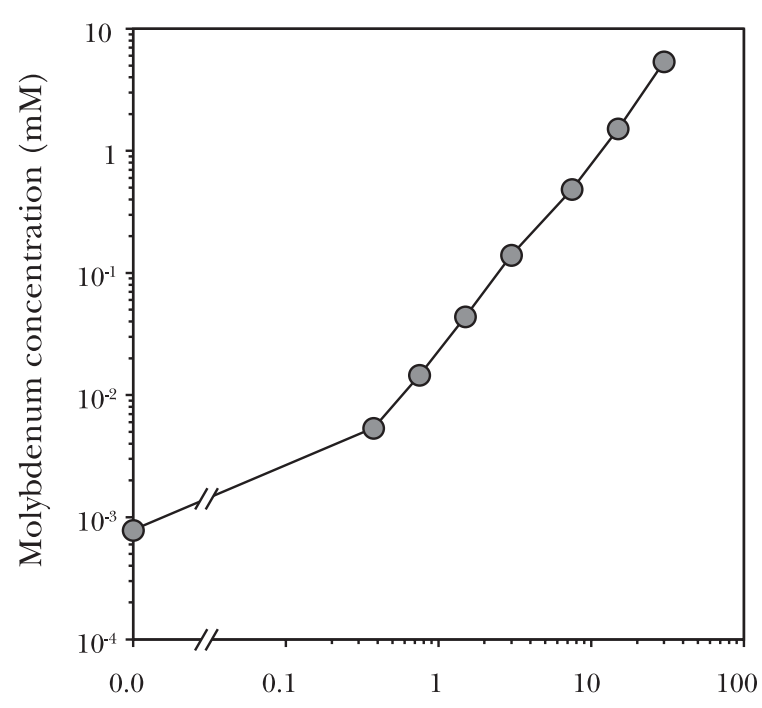

Applied amount of potassium molybdate $\left(\mathrm{mmol} \mathrm{kg}{ }^{-1}\right.$ dried soil)

Fig. 2. Molybdenum concentration of soil solution just after sowing.

Error bars representing standard errors $(n=2)$ were too small to be shown.

than $0.75 \mathrm{mmol} \mathrm{kg}^{-1}$ or no less than $30 \mathrm{mmol} \mathrm{kg}^{-1}$. However, rates improved when the applied amount of potassium molybdate was $1.5-15 \mathrm{mmol} \mathrm{kg}{ }^{-1}$. It resulted in concentrations of molybdenum in the soil solutions of $0.04-1.5 \mathrm{mM}$ because molybdenum concentration in the soil solution increased in proportion to the potassium molybdate applied (Fig. 2).

The seedling growth was delayed with the amount of potassium molybdate when the establishment rates were improved between $1.5-15 \mathrm{mmol} \mathrm{kg}{ }^{-1}$ of applied

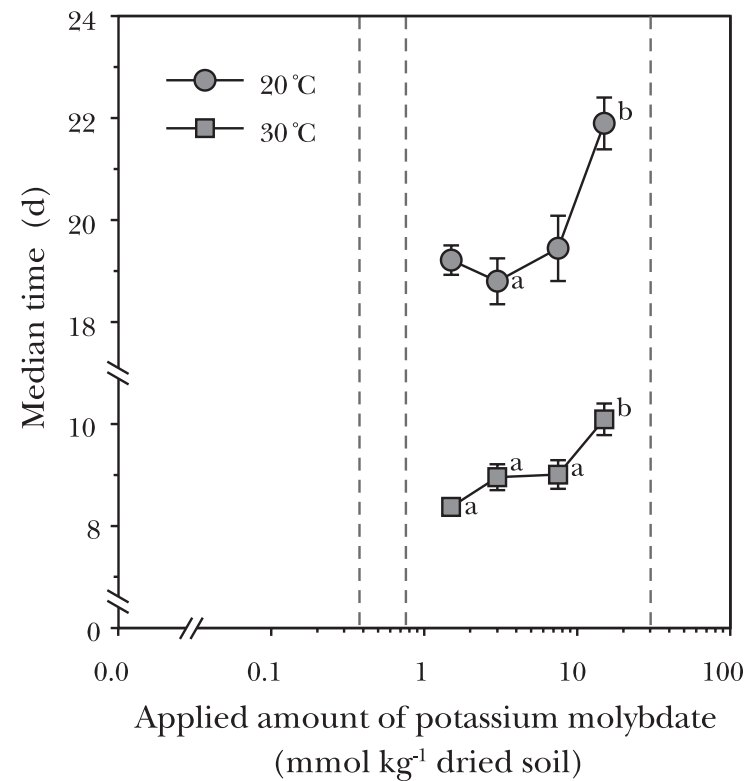

Fig. 3. Effect of molybdate on time to seedling establishment. Median time was not calculated when the rate of establishment was less than $20 \%$, in which amount of potassium molybdate applied was $0.00,0.38,0.75$, and 30 mmol kg-1 dried soil as indicated by gray broken line. Error bars represent standard errors $(n=6)$. Different alphabets mean significant difference at $5 \%$ in each temperature (Tukey's multiple comparison).

molybdate. The median time to establishment was increased with the amount of potassium molybdate applied at both temperatures although the medium time at $30^{\circ} \mathrm{C}$ was half that at $20^{\circ} \mathrm{C}$ (Fig. 3).

The color of methylene blue near the seeds changed from blue to colorless about $2 \mathrm{~d}\left(30^{\circ} \mathrm{C}\right)$ or $3 \mathrm{~d}\left(20^{\circ} \mathrm{C}\right)$ after 


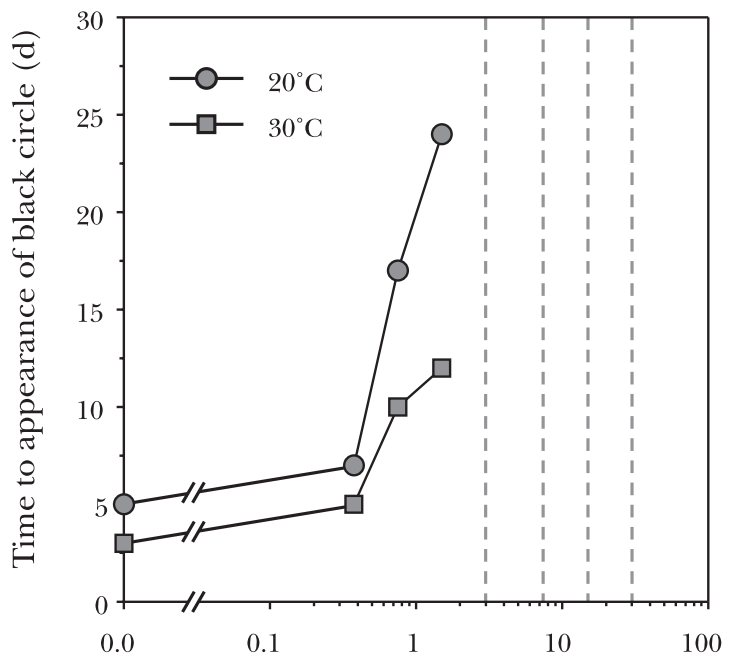

Applied amount of potassium molybdate ( $\mathrm{mmol} \mathrm{kg}^{-1}$ dried soil)

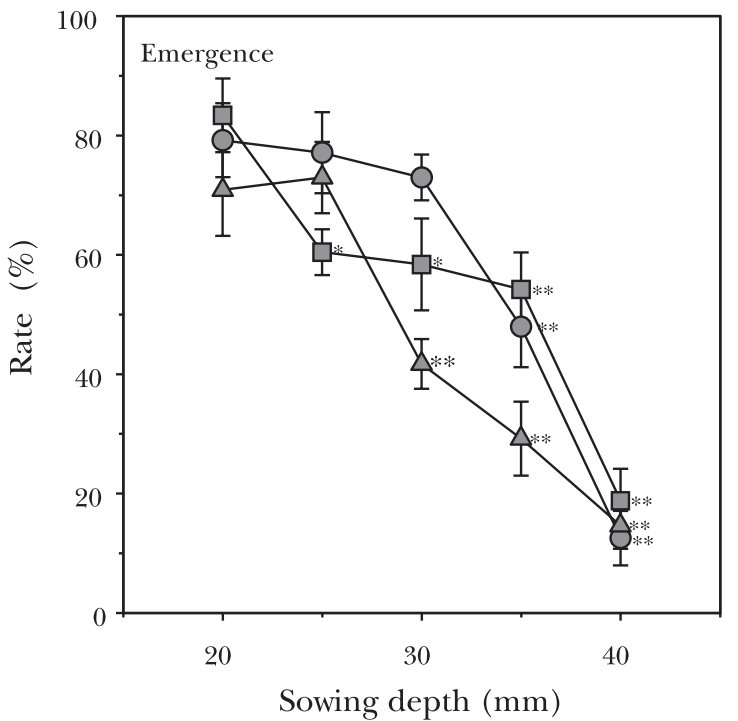

Fig. 4. Effect of molybdate on time to appearance of black circles.

Time to appearance of black circle means the time in which black circles first appeared in a pot in which eight seeds were sown. Black circles did not appear when applied amount of potassium molybdate were $3.0,7.5,15$, and $30 \mathrm{mmol}$ $\mathrm{kg}^{-1}$ dried soil as indicated by gray broken line.

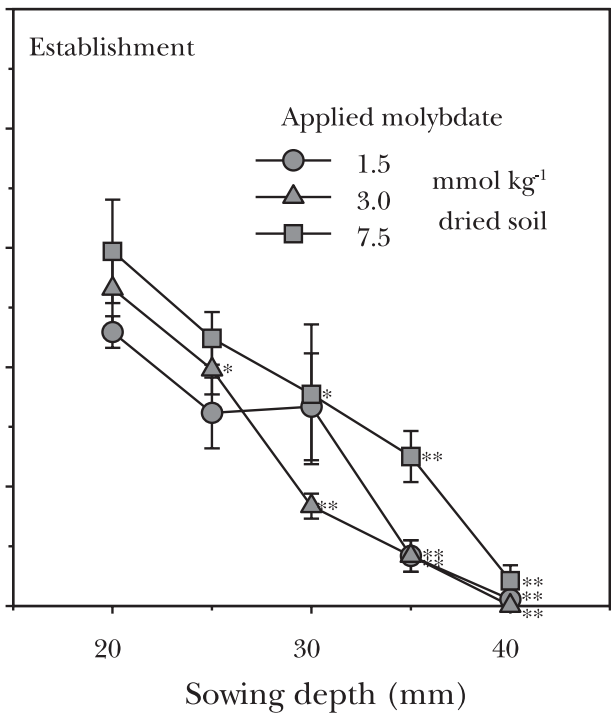

Fig. 5. Effect of sowing depth on rates of seedling emergence and establishment.

Rice seeds were sown in soils to which different amounts of potassium molybdate were applied. Sown seeds were incubated at $30^{\circ} \mathrm{C}$. Error bars represent standard errors $(n=6)$. $* * p<0.01$, $* p<0.05$ vs. when sowing depth was $20 \mathrm{~mm}$ (Dunnett's multiple comparison).

seed sowing when potassium molybdate was not applied. The number of days required for this color change trended to slightly increase with the increase in the applied amount of potassium molybdate (data not shown).

Circular black stains, which may be iron sulfides (Kumada, 1949; Hagiwara et al., 1987), appeared near the seeds only when the amount of potassium molybdate applied was no more than $1.5 \mathrm{mmol} \mathrm{kg}^{-1}$ (Fig. 4). The appearance of these black circles was delayed by an increase in the applied amount of potassium molybdate at either temperature although black circles developed quickly in pots maintained at $30^{\circ} \mathrm{C}$ than in those maintained at $20^{\circ} \mathrm{C}$.

\section{Effect of sowing depth on establishment with molybdenum (Exp. 2)}

The rates of emergence and establishment of rice seeds decreased with the increase in sowing depth (Fig. 5). When the sowing depth was $40 \mathrm{~mm}$, establishment rates were almost zero on every applied amount of potassium molybdate. The difference of applied amount of potassium molybdate in the range from 1.5 to $7.5 \mathrm{mmol} \mathrm{kg}^{-1}$ did not have a significant effect on these rates.

\section{Effect of molybdenum on soil redox potentials (Exp. 3)}

The redox potentials of soil near the seeds declined rapidly and became almost constant at about $-0.2 \mathrm{~V}$ at $4 \mathrm{~d}$ $\left(20^{\circ} \mathrm{C}\right)$ or $2 \mathrm{~d}\left(30^{\circ} \mathrm{C}\right)$ after sowing (Fig. 6). Redox 


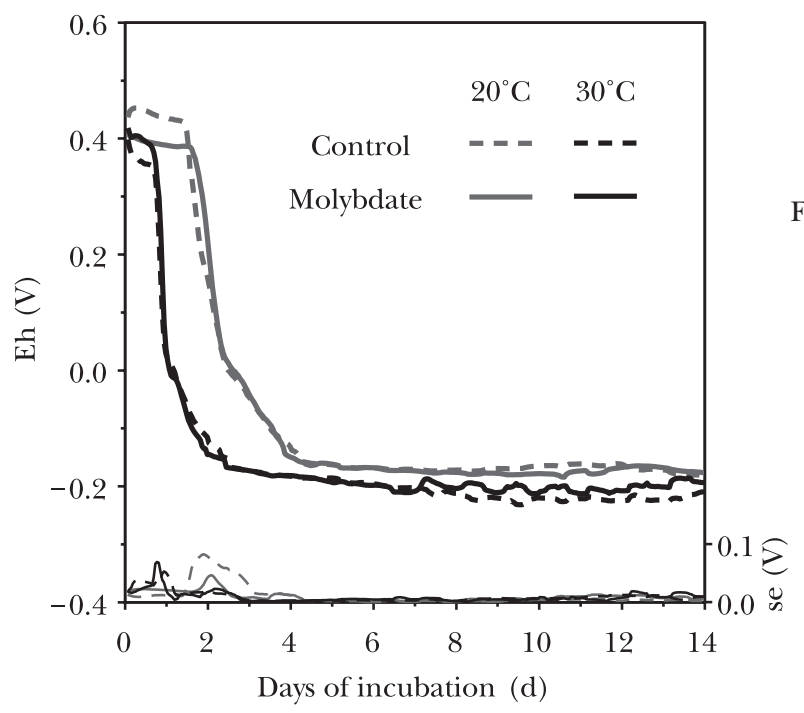

Fig. 6. Effect of molybdates on the redox potential of soil near the seeds.

Seeds were sown in submerged soil to which either nothing (Control) or 1.5 mmol potassium molybdate $\mathrm{kg}^{-1}$ dried soil (Molybdate) was added. Incubation at 20 or $30^{\circ} \mathrm{C}$ was started just after sowing. Six measurements were made. For each condition at $30^{\circ} \mathrm{C}$, one measurement was rejected as an outlier. Standard errors (se) are represented by the thin lines at the bottom of the graph.

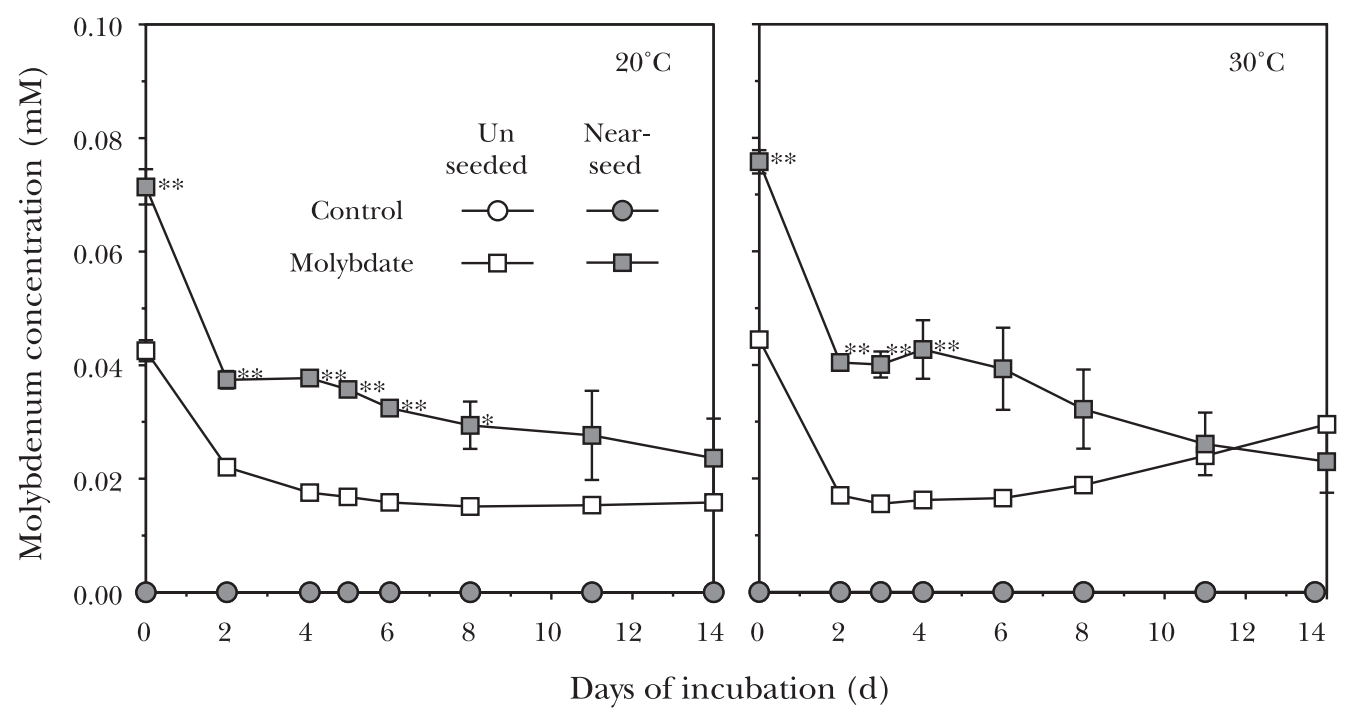

Fig. 7. Effect of seeds on molybdenum concentrations in the soil solution.

Seeds were sown in half of the pots, which were half-filled with puddled soil to which either nothing (Control) or $1.5 \mathrm{mmol}$ potassium molybdate $\mathrm{kg}^{-1}$ dried soil (Molybdate) was added. Incubation at 20 or $30^{\circ} \mathrm{C}$ was started after sowing. In the graph legends, "Near-seed" means the soil solution near the seeds, and "Unseeded" means the solution of unseeded soils. Molybdenum concentrations in the soil solution were constantly zero when potassium molybdate was not added (Plots of unseeded and near-seed overlapped in control). Error bars represent standard error ( $n=4$ for "Near-seed", $n=3$ for "Unseeded"). **, * mean significant difference at $1,5 \%$ by the presence or absence of seeds.

potentials were unaffected by the addition of potassium molybdate.

\section{Effect of molybdenum on sulfur and molybdenum concentrations (Exp. 4)}

The molybdenum concentration in soil solutions independently of existence of seeds was about $0.00 \mathrm{mM}$ when potassium molybdate was not applied (Fig. 7). When potassium molybdate was applied, the molybdenum concentration in the soil solution was $0.04-0.08 \mathrm{mM}$ at first, then rapidly decreased and stabilized at $0.01-0.03$
$\mathrm{mM}$. The concentration in the soil solution near the seeds was higher than that in unseeded soil for about $1 \mathrm{wk}$ after sowing. Temperature had little effect on molybdenum concentration.

The sulfur concentration in soil solution near the seeds decreased, while that in unseeded soil hardly decreased (Fig. 8). This decrease began $5 \mathrm{~d}\left(20^{\circ} \mathrm{C}\right)$ or $2 \mathrm{~d}\left(30^{\circ} \mathrm{C}\right)$ after sowing when potassium molybdate was not applied. Application of potassium molybdate delayed this decrease in sulfur concentration; the decrease began at $11 \mathrm{~d}\left(20^{\circ} \mathrm{C}\right)$ or $8 \mathrm{~d}\left(30^{\circ} \mathrm{C}\right)$ after sowing. 


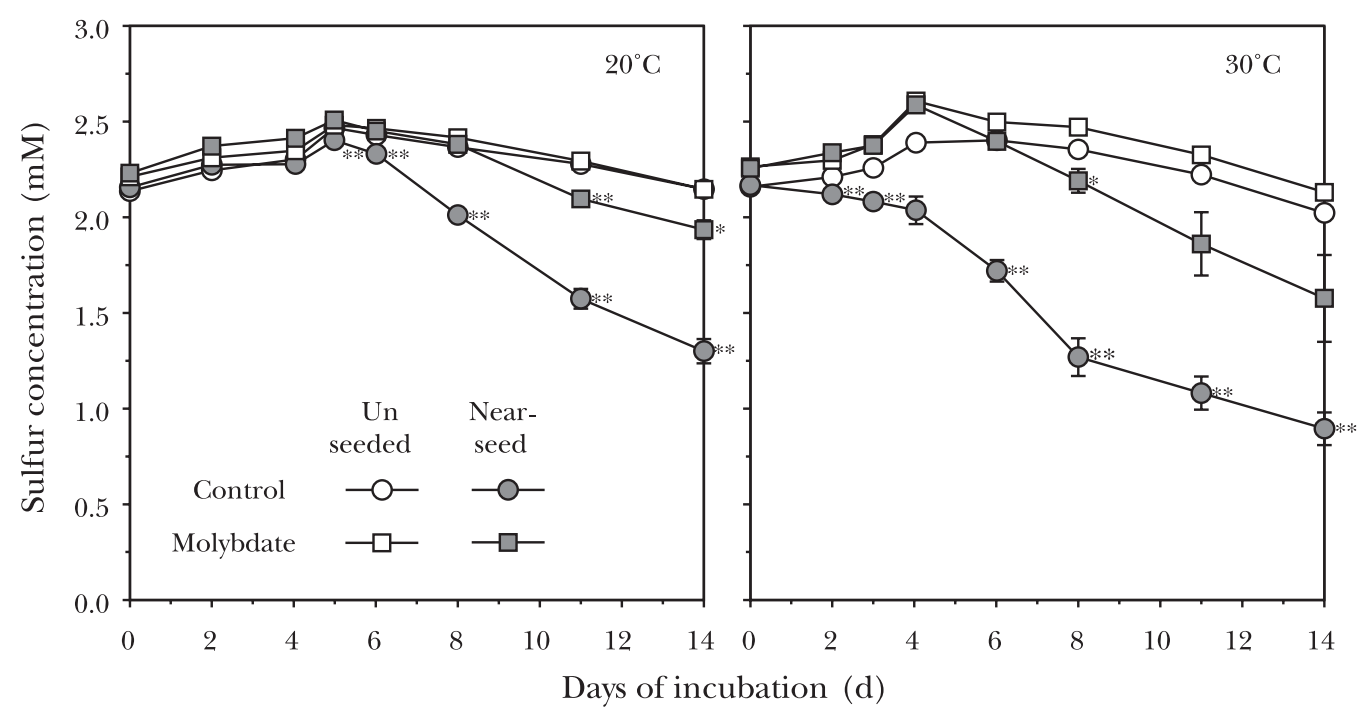

Fig. 8. Effect of seeds on sulfur concentrations in the soil solution.

Seeds were sown in half of the pots, which were half-filled with puddled soil to which either nothing (Control) or $1.5 \mathrm{mmol}$ potassium molybdate $\mathrm{kg}^{-1}$ dried soil (Molybdate) was added. Incubation at 20 or $30^{\circ} \mathrm{C}$ was started after sowing. In the graph legends, "Near-seed" means the soil solution near the seeds, and "Unseeded" means the solution of unseeded soils. Error bars represent standard error ( $n=4$ for "Near-seed", $n=3$ for "Unseeded"). **, * mean significant difference at $1,5 \%$ by the presence or absence of seeds.

\section{Discussion}

\section{Molybdate improves establishment}

The establishment rate of rice seeds was less than $60 \%$ at best and was zero at least. The reason for this poor establishment may be the generation of sulfide caused by the addition of ammonium sulfate and the keeping of submergence (Kawaguchi, 1944), not by the property of the soil used, which was the same as in previously reported experiments (Hara, 2013).

Seedling establishment improved regardless of temperature $\left(20\right.$ or $\left.30^{\circ} \mathrm{C}\right)$ without water drainage when $1.5-15 \mathrm{mmol} \mathrm{kg}^{-1}$ potassium molybdate was applied to the soil (Fig. 1). This effect was not caused by potassium ions because $1.0 \mathrm{mmol} \mathrm{\textrm {kg } ^ { - 1 }}$ potassium chloride was added to every pot. Molybdenum is an essential plant micronutrient and is sometimes used as a fertilizer (Marschner, 1995a; MacLeod et al., 1997); thus, the possibility that the nutritional effect of molybdenum resulted in the improved establishment cannot be ruled out. However, this probability is low because plants require such low concentrations of molybdenum relative to those of other micronutrients (Marschner, 1995a). Rather, the application of molybdate ions likely removed the factor that suppressed establishment.

The redox potential of the seed environment was unaffected by the addition of molybdates, declined rapidly and became constant at about $-0.2 \mathrm{~V}$ (Fig. 6). This potential was the level at which sulfide ions could be generated near the seeds because their generation begins when redox potential declines to approximately $-0.05--0.18 \mathrm{~V}$ (Marschner, 1995b). However, establishment of rice seedlings in submerged soil was improved by the application of molybdate. This indicates that the application of molybdate would improve establishment without affecting redox potential, although molybdate ions $\left(\mathrm{MoO}_{4}{ }^{2-}\right)$ contain oxygen. In contrast, calcium peroxide, which is generally used as an oxygen-generating chemical in direct rice seeding, improves establishment by maintaining a high redox potential (Hagiwara et al., 1990).

Circular black stains that appeared near the seeds were likely iron sulfides (Kumada, 1949; Hagiwara et al., 1987). The appearance of the stains implied the generation of sulfide ions. This was supported by the decrease of sulfur concentrations near the seeds (Fig. 8) because soluble sulfate ions (soluble sulfur) changed into insoluble iron sulfides (insoluble sulfur) through the generation of sulfide ions under reducing condition near the seeds. The appearance of black circle stains and the decrease of sulfur concentration near the seeds were delayed when molybdate of no more than $1.5 \mathrm{mmol} \mathrm{kg}{ }^{-1}$ was applied (Figs. 4 and 8). In addition, circular black stains did not appear when the molybdate application was no less than 3 mmol kg-1 (Fig. 4), for which the corresponding concentration of molybdate in the soil solution was no less than $0.14 \mathrm{mM}$ (Fig. 2). The growth of sulfate-reducing bacteria, which generate sulfide ions, was reported to be inhibited to half at molybdate concentrations of $0.2 \mathrm{mM}$ or more (Biswas et al., 2009). This implies that the application of molybdate inhibits the generation of sulfide ions 
because the molybdate ion is analogous to the sulfate ion, which is the precursor of the sulfide ion (Hori et al., 1990; Marschner, 1995a; MacLeod et al., 1997).

Establishment rates improved by application of potassium molybdate at a rate of $1.5-15 \mathrm{mmol} \mathrm{kg}^{-1}$ (Fig. 1 ), for which the corresponding concentration of molybdate in soil solution was $0.04-1.5 \mathrm{mM}$. This suggests that application of molybdate to soil improves establishment by inhibiting the generation of sulfide ions, and also that the main factor suppressing the establishment of rice in sulfate-applied submerged soil might be the generation of sulfide ions. My previous finding that suppression of establishment in sulfate-applied submerged soil was offset by autoclaving soil (Hara, 2013) also supports the hypothesis that establishment is impaired by sulfide ions produced by sulfate-reducing bacteria (Furusaka, 1968).

Seedling establishment was not improved when molybdate was added at a rate of $30 \mathrm{mmol} \mathrm{kg}{ }^{-1}$ or more, although emergence improved and the black iron sulfides did not appear (Figs. 1 and 4). In addition, the growth of rice seedlings delayed with the increase in amount of molybdate applied (Fig. 3). The delayed loss of methylene blue color near the seeds in soil treated with a higher amount of molybdate (Exp. 1) might have been caused by this delayed growth rate. These results imply that a high concentration of molybdate might not only inhibit the production of sulfide ions by bacteria but also impair the growth of rice plants, possibly by interfering with plant sulfur utilization. While establishment was suppressed by high concentrations of molybdates, emergence was not (Fig. 1); this implies that seeds might have their own supply of sulfur during emergence, but rely on an external supply of sulfur during establishment.

Accordingly, to improve rice seedling establishment, molybdate application is best maintained at roughly between 1.5 and $15 \mathrm{mmol} \mathrm{kg}$, which corresponds to soil concentrations of approximately $0.04-1.5 \mathrm{mM}$.

\section{Efficacy of molybdate application}

Molybdenum concentrations rapidly decreased and stabilized at $0.2-0.4 \mathrm{mM}$ after $2 \mathrm{~d}$ (Fig. 7). Because molybdenum is thought to exist in the anionic form of molybdate ions, it would immediately exchange with other anions or react in the soil soon after their application. Soil solution concentrations of molybdenum were higher near the seeds than in soil without seeds, although the reason for this difference is unclear. The molybdenum concentration in the soil solution near the seeds decreased slightly with time, although that without seeds did not decrease. Molybdenum may react with other components, such as enzymes of bacteria in place of sulfur or might be reduced to insoluble molybdenum sulfide (Biswas et al., 2009).
The application of $3 \mathrm{mmol} \mathrm{kg}^{-1}$ potassium molybdate appeared to inhibit the generation of sulfide ions (Fig. 4) during the establishment period. The positive effect on establishment might be maintained by a small amount of molybdenum. In contrast, the calcium peroxides generally used in direct seeding are exhausted rapidly (Hagiwara et al., 1990).

Establishment decreased with sowing depth, although the establishment rate was slightly higher in pots treated with a high concentration $\left(7.5 \mathrm{mmol} \mathrm{kg}{ }^{-1}\right)$ of molybdate (Fig. 5). The trend in emergence rate was similar to that of establishment, suggesting that the establishment rate was affected by emergence rate. The impairment of emergence rate with increased sowing depth might be caused by a limited elongation ability of the coleoptile, not by the generated sulfide ions. Generally, the desired sowing depth of seeds coated with calcium peroxide (followed by water drainage) is $10-20 \mathrm{~mm}$ (Yoshinaga et al., 2007). The establishment percentage under molybdate application without water drainage was about $50 \%$ at a sowing depth of $20 \mathrm{~mm}$ (Fig. 5). This result indicates that the effects of sowing depth would be similar for application of both molybdate and calcium peroxide and that rice seeds should be sown at shallow depths if the generation of harmful sulfide ions was suppressed by molybdate.

\section{Mechanism of seed damage by submergence}

Molybdenum has been reported to suppress the generation of sulfide ions from sulfate ions by sulfatereducing bacteria (Hori et al., 1990; Biswas et al., 2009). The distinct improvement in establishment following molybdate application observed in this study implies that a factor of impaired seedling establishment in direct seeding is the sulfide ions generated by sulfate-reducing bacteria, especially in sulfur-rich submerged soil. This conclusion is also supported by a previous study, which found that sulfate application suppressed the establishment of rice seeds sown in submerged soil and that redox potential quickly declined to a level below that required for sulfide ion generation, even at low temperatures (Hara, 2013).

Rice seedlings were established even under low redox potential if sulfide ions were not generated by the application of molybdate (Figs. 1,6). This indicates the possibility of establishment of rice seedlings even in environments of low redox potential with no oxygen, if sulfide ions are not generated or if sulfate concentrations are low, highlighting the adaptation of rice to the submerged environment.

Ferrous ions or organic acids may also suppress the establishment of rice plants (Hagiwara and Imura, 1993). In this study, however, rice seedlings were established even when iron concentrations in the soil solution near the seeds exceeded $0.5 \mathrm{mM}$ (Exp. 4, data not shown). Accordingly, ferrous ions and organic acids might only 
further impair rice establishment if the roots of the rice plants have already been damaged by sulfide ions. In addition, ferrous ions and organic acids might activate the generation of sulfide ions; ferrous ions have been reported to be a limiting factor in the growth of sulfate-reducing bacteria, and organic acids have been found to be electron donors and carbon sources in dissimilatory sulfatereduction of sulfate-reducing bacteria (Marchal et al., 2001).

Studies on the use of seed coating which requires less molybdenum than application to the soil are underway.

\section{Acknowledgements}

I thank Dr. K. Toriyama (JIRCAS) for helpful comments on the manuscript; Dr. Y. Takahashi (Tohoku Univ.) for advice on sulfate-reducing bacteria; Dr. K. Tasaka, Mr. K. Masuda, and Dr. K. Nakano (NARO) for general advice; and Mrs. T. Tajima, Mrs. K. Sekimoto, Mrs. S. Nakao, and Mrs. N. Takuma (NARO) for assistance with the experiments.

\section{References}

Biswas, K.C., Woodards, N.A., Xu H. and Barton, L.L. 2009. Reduction of molybdate by sulfate-reducing bacteria. BioMetals 22 : 131-139.

Furuhata, M. 2009. Improvement of seedling emergence and establishment of rice direct seeded in flooded paddy fields. Jpn. J. Crop Sci. 78: 153-162*.

Furusaka, C. 1968. Studies on the activity of sulfate reducers in paddy soil. Bull. Inst. Agr. Res. Tohoku Univ. 19: 101-184**.

Hagiwara, M., Imura, M. and Mitsuishi, S. 1987. Oxidation-reduction state in the vicinity of the paddy rice seed sown into flooded soil. Jpn. J. Crop Sci. 56: 356-362**.

Hagiwara, M., Imura, M. and Mitsuishi, S. 1990. Local soil reduction in the vicinity of the paddy rice seed coated with oxygen generating chemicals in relation to germination and emergence. Jpn. J. Crop Sci. 59. 56-62*.

Hagiwara, H. and Imura, M. 1993. Seedling emergence and establishment of direct-sown paddy rice in soils incorporated with substances produced in reductive paddy soil. Jpn. J. Crop Sci. 62: 609-613*.

Hara, Y. 1999. Calculation of population parameters using Richards function and application of indices of growth and seed vigor to rice plants. Plant Prod. Sci. 2: 129-135.

Hara, Y. 2013. Suppressive effect of sulfate on establishment of rice seedlings in submerged soil may be due to sulfide generation around seeds. Plant Prod. Sci. 16: 50-60.

Hori, K., Inubushi, K., Matsumoto, S. and Wada, H. 1990. Appropriate concentration of inhibitors for methane formation and sulfate reduction in submerged soil system. Jpn. J. Soil Sci. Plant Nutr. 61: $647-648^{* *}$.

Kawaguchi, K. 1944. Adverse effect of ammonium sulfate on seedling and seed germination in soil under paddy conditions. Agronomy Research (Nougaku kenkyu) 36: 484-496***. (titles of paper and journal translated by the present author.)

Kumada, K. 1949. Investigation on the rhizosphere of rice seedling. Part 1: On the microscopic structure of the rhizosphere and oxidative power of root. Jpn. J. Sci. Soil Manure 19: 119-124***.

MacLeod, J.A., Gupta, U.C. and Stanfield, B. 1997. Molybdenum and sulfur relationships in plants. In U.C. Gupta ed., Molybdenum in Agriculture. Cambridge University Press, Cambridge. 229-244.

Marchal, R., Chaussepied, B. and Warzywoda, M. 2001. Effect of ferrous ion availability on growth of a corroding sulfate-reducing bacterium. Int. Biodeterior. Biodegradation 47: 125-131.

Marschner, H. 1995a: Molybdenum. In Marschner ed. Mineral Nutrition of Higher Plants. 2nd ed. Academic Press, London. 369379.

Marschner, H. 1995b: Waterlogged and flooded soils. In Marschner ed. Mineral Nutrition of Higher Plants. 2nd ed. Academic Press, London. 626-641.

Okajima, H. and Takagi, S. 1959: Harmful effect of hydrogen sulfide on the rice plant growth. Jpn. J. Sci. Soil Manure 29: 577-582***.

Osugi, S. and Kawaguchi, K. 1938. On the reduction of sulfates in paddy field soil. Jpn. J. Sci. Soil Manure 12: 453-462*.

Yamamoto, A., Hatanaka, A. and Ito, O. 2004. Inhibition of seedling establishment by nitrogen application in direct sowing culture of paddy rice in cold region. Soil Sci. Plant Nutr. 50: 103-107.

Yamauchi, M. 1997. Rice crop establishment in flooded soil. Jpn. J. Soil Sci. Plant Nutr., 68: 467-476***.

Yoshinaga, S., Sakaiya, E., Yoshida, H., Yamamoto, A., Wakamatsu, K., Kikuchi, E. and Honma, M. 2007. Effects of the amount of seed coating with oxygen-generating products on the seedling establishment of submerged direct-seeded rice (Oryza sativa L.) in Tohoku region. Jpn. J. Crop Sci. 76: 445-449*.

\footnotetext{
* In Japanese with English abstract.

** In Japanese with English summary.

*** In Japanese.
} 